\title{
Amyloid beta, TNF $\alpha$ and FAIM-L; approaching new therapeutic strategies for AD
}

\author{
Paulina Carriba ${ }^{1,2,3 *}$ and Joan X. Comella ${ }^{1,2,3}$ \\ 1 Institut de Recerca de l'Hospital Universitari de la Vall d'Hebron (VHIR), Barcelona, Spain \\ ${ }^{2}$ Facultat de Medicina, Departament de Bioquímica i Biologia Molecular, Institut de Neurociències, Universitat Autònoma de Barcelona, Bellaterra, Spain \\ ${ }^{3}$ Centro de Investigación Biomèdica en Red sobre Enfermedades Neurodegenerativas (CIBERNED), Spain \\ ${ }^{*}$ Correspondence: paulina.carriba@gmail.com \\ Edited by: \\ Angel Cedazo-Minguez, Karolinska Institutet, Sweden \\ Reviewed by: \\ George Perry, University of Texas at San Antonio, USA \\ Laura Mateos, Karolinska Institutet, Sweden \\ Maria Ramirez, University of Navarra, Spain
}

Keywords: soluble amyloid beta, TNF $\alpha$, neuroinflammation, neurodegeneration, FAIM-L

\section{A commentary on}

Successful therapies for Alzheimer's disease: why so many in animal models and none in humans?

by Franco $R$, Cedazo-Minguez A. Front Pharmacol (2014) 5:146. doi:10.3389/fphar. 2014.00146

The aim of this commentary is to complement the review of Franco and CedazoMinguez (1).

\section{ALZHEIMER'S DISEASE AND AMYLOID BETA}

Defining characteristics of Alzheimer's disease $(\mathrm{AD})$ are memory defects, synaptic alterations, presence of neuroinflammatory mediators, and a progressive neurodegeneration. One of the histopathological hallmarks of the disease is the presence of amyloid beta $(A \beta)$ plaques; however, it seems that soluble oligomers, also called $\mathrm{A} \beta$-derive-diffusible-ligands (ADDLs), are the really toxic species involved in the pathogenesis of $\mathrm{AD}(2)$. ADDLs are a blend of several sizes of oligomeric $A \beta$ species (3). This suggests that most of the effects on the neurons cannot be attributed to interactions with specific receptors, but rather to interaction and alteration of the proteins and lipids within the cell membranes (4). ADDLs have been detected in $\mathrm{AD}$ patients (5), increasing their content with severity (6). Dimers isolated from AD brains impair LTP, enhance LTD, reduce dendritic spines density, and correlate with clinical state (7). Also, they are able to induce hyperphosphorylation of Tau and neuritic dystrophy
(8). Soluble oligomers of $A \beta$ are toxic for the neurons (9). They also cause synaptic dysfunction (10) through the activation of caspase-3 (11). Moreover, the inflammatory response characterized by the secretion of various products is initiated by the glial cells when these cells detect $\mathrm{A} \beta$ (12). Thus, $A \beta$ appears to be a decisive trigger for the development of this neurodegenerative disorder.

\section{NEUROINFLAMMATION AND NEURODEGENERATION, TWO OF THE CHARACTERS IN THE PROGRESSION OF THE DISEASE}

The neuronal loss observed in the $\mathrm{AD}$ brains, as occurs in other neurodegenerative diseases, is produced mainly by apoptosis $(13,14)$. Sustained neuroinflammatory response contributes to the progression of the disease $(15,16)$, which ultimately it strengthens the neuronal death (17).

For their physiological importance, both processes are highly regulated; consequently, they can be harmful when deregulated. Apoptosis can be initiated through the mitochondria - intrinsic pathway or by the stimulation of death receptors (DRs) - extrinsic pathway - [see Ref. (18)]. DRs are cell surface receptors that belong to the TNF super-family. They are able to trigger apoptosis upon ligand binding. DRs and their ligands are expressed physiologically in the brain (19), with important roles in brain development $(20,21)$ and in cellular homeostasis in adulthood (22). In neurons, in normal conditions, the activation of these receptors does not initiate apoptosis $(23,24)$. Likewise, inflammation is generally a beneficial physiological response. In fact, it has been described that the initial glial inflammatory response in $\mathrm{AD}$ is protective $(25,26)$.

\section{TNF $\alpha$ IN THE CROSS-ROAD BETWEEN INFLAMMATION AND APOPTOSIS}

In brain, TNF $\alpha$ plays a central role in neuroinflammation, apoptosis, and also in the control of the synaptic strength $(27,28)$. The TNF $\alpha$ gene maps within the class III region of human leukocyte antigen (HLA). Several polymorphisms were detected associated to $\mathrm{AD}$ in this region, and systematic meta-analyses concluded that TNF $\alpha$ is a susceptibility gene in the disease (29). High levels of TNF $\alpha$ have been detected in $\mathrm{AD}$ patients $(30,31)$. TNF system has been proposed as a neurotherapeutic target (32), and its role in animal models of $\mathrm{AD}$ has been reported (33-35). However, its function in the disease is not clear. It has been described that TNF $\alpha$ is a contributor of the disease $(36,37)$, although also that it can protect from the $A \beta$ toxicity $(38,39)$.

$\mathrm{TNF} \alpha$ can stimulate two signaling pathways, survival or death (40). The induction of survival pathways depend on $\mathrm{NF \kappa} B$ (40) and/or FLIP-L-dependent activation of ERK (41). In normal conditions, TNF $\alpha$ is not toxic for the neurons, indicating that several regulatory proteins prevent the induction of apoptosis at various stages of TNF signaling (42). Expressed exclusively in neurons, the long form of Fas apoptotic inhibitory molecule (FAIM) protein (FAIM-L) is able to regulate the signaling of TNF $\alpha$. The down-regulation of FAIM-L 
sensitizes neurons to death induced by TNF $\alpha$ and also by FAS (43). In Parkinson's disease, it has been proposed that FAIM-L expression could be reduced in dopaminergic neurons, being then this type of neurons more vulnerable to FAS-induced death (44). We have evidences that ADDLs reduce the expression of FAIM-L. The reduction of FAIM-L changes the response mediated by TNF $\alpha$ against the A $\beta$ toxicity, from protection to a contributor in the neuronal death, thus, accelerating the neurodegenerative process (paper under review).

\section{NEW PERSPECTIVES IN FINDING POTENTIAL TARGETS}

FAIM-L, modulating the function of the TNF $\alpha$ in neurons, would be an example of target molecule able to ameliorate both neurodegeneration and deleterious neuroinflammation. Although speculative, it is possible to hypothesize that the reduction in the neuronal loss would result in an improvement also in the cognition. $A \beta$ is able to cause all the features observed in the disease, thus, targets able to act in more than one of the aspects of the disease would be more useful. However, this type of strategy only would be effective in the prevention of disease progression rather than in the prevention of the disease. Moreover, whereas we do not have good biomarkers for early detection, it seems difficult that potential $\mathrm{AD}$ patients $(99 \%$ of the cases correspond to the non-familiar or sporadic) without any symptom or diagnosis would take drugs to prevent $\mathrm{AD}$ in the future, unless these were supplements or healthy habits. Thus, therapies able to prevent the progression of the disease acquire greater relevance.

\section{ACKNOWLEDGMENTS}

This work was funded by the Spanish Government's "Ministerio de Sanidad y Consumo" (CIBERNED grants to Joan X. Comella CB06/05/1104; PI2010/08 and 2013/01); "Ministerio de Economía y Competitividad" (SAF2010-19953 to Joan X. Comella), and by the "Generalitat de Catalunya" (Suport als Grups de Recerca Consolidats 2009SGR346). Paulina Carriba was awarded a "Beatriu de Pinos" postdoctoral grant from the "Generalitat de Catalunya" co-financed by the FP7-PeopleCOFUND Programme.

\section{REFERENCES}

1. Franco R, Cedazo-Minguez A. Successful therapies for Alzheimer's disease: why so many in animal models and none in humans? Front Pharmacol (2014) 5:146. doi:10.3389/fphar.2014.00146

2. Mc Donald JM, Savva GM, Brayne C, Welzel AT, Forster G, Shankar GM, et al. The presence of sodium dodecyl sulphate-stable Abeta dimers is strongly associated with Alzheimer-type dementia. Brain (2010) 133:1328-41. doi:10.1093/brain/ awq065

3. Benilova I, Karran E, De Strooper B. The toxic A $\beta$ oligomer and Alzheimer's disease: an emperor in need of clothes. Nat Neurosci (2012) 15:349-57. doi: $10.1038 / \mathrm{nn} .3028$

4. Campioni S, Mannini B, Zampagni M, Pensalfini A, Parrini C, Evangelisti E, et al. A causative link between the structure of aberrant protein oligomers and their toxicity. Nat Chem Biol (2010) 2:140-7. doi:10.1038/nchembio.283

5. Lacor PN, Buniel MC, Chang L, Fernandez SJ, Gong Y, Viola KL, et al. Synaptic targeting by Alzheimer's-related amyloid beta oligomers. J Neurosci (2004) 45:10191-200. doi:10.1523/ JNEUROSCI.3432-04.2004

6. Lambert MP, Velasco PT, Chang L, Viola KL, Fernandez S, Lacor PN, et al. Monoclonal antibodies that target pathological assemblies of Abeta. J Neurochem (2007) 100:23-35. doi:10.1111/j. 1471-4159.2006.04157.x

7. Shankar GM, Li S, Mehta TH, Garcia-Muñoz A, Shepardson NE, Smith I, et al. Amyloid-beta protein dimers isolated directly from Alzheimer's brains impair synaptic plasticity and memory. Nat Med (2008) 14:837-42. doi:10.1038/nm1782

8. Jin M, Shepardson N, Yang T, Cheng G, Walsh D, Selkoe DJ. Soluble amyloid beta-protein dimers isolated from Alzheimer cortex directly induce Tau hyperphosphorylation and neuritic degeneration. Proc Natl Acad Sci U S A (2011) 108:5819-24. doi:10.1073/pnas.1017033108

9. De Felice FG, Velasco PT, Lambert MP, Viola K, Fernandez SJ, Ferreira ST, et al. Abeta oligomers induce neuronal oxidative stress through an $\mathrm{N}$ methyl-D-aspartate receptor-dependent mechanism that is blocked by the Alzheimer drug memantine. J Biol Chem (2007) 282:11590-601. doi:10.1074/jbc.M607483200

10. Walsh DM, Klyubin I, Fadeeva JV, Cullen WK, Anwyl R, Wolfe MS, et al. Naturally secreted oligomers of amyloid beta protein potently inhibit hippocampal long-term potentiation in vivo. Nature (2002) 416:535-9. doi:10. 1038/416535a

11. Jo J, Whitcomb DJ, Olsen KM, Kerrigan TL, Lo SC, Bru-Mercier G, et al. A $\beta(1-42)$ inhibition of LTP is mediated by a signaling pathway involving

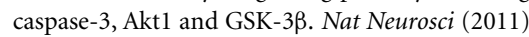
14:545-7. doi: $10.1038 / \mathrm{nn} .2785$

12. Butovsky O, Koronyo-Hamaoui M, Kunis G, Ophir E, Landa G, Cohen H, et al. Glatiramer acetate fights against Alzheimer's disease by inducing dendritic-like microglia expressing insulin-like growth factor 1. Proc Natl Acad Sci U S A (2006) 103:11784-9. doi:10.1073/pnas.0604681103

13. Cotman CW, Anderson AJ. A potential role for apoptosis in neurodegeneration and Alzheimer's disease. Mol Neurobiol (1995) 10:19-45. doi:10. 1007/BF02740836
14. Mattson MP. Apoptosis in neurodegenerative disorders. Nat Rev Mol Cell Biol (2000) 1:120-9. doi:10.1038/35040009

15. Saijo K, Winner B, Carson CT, Collier JG, Boyer L, Rosenfeld MG, et al. A Nurr1/CoREST pathway in microglia and astrocytes protects dopaminergic neurons from inflammation-induced death. Cell (2009) 137:47-59. doi:10.1016/j.cell.2009.01.038

16. Glass CK, Saijo K, Winner B, Marchetto MC, Gage FH. Mechanisms underlying inflammation in neurodegeneration. Cell (2010) 140:918-34. doi:10. 1016/j.cell.2010.02.016

17. Akiyama H, Barger S, Barnum S, Bradt B, Bauer J, Cole GM, et al. Inflammation and Alzheimer's disease. Neurobiol Aging (2000) 21:383-421. doi:10. 1016/S0197-4580(00)00124-X

18. Wilson NS, Dixit V, Ashkenazi A. Death receptor signal transducers: nodes of coordination in immune signaling networks. Nat Immunol (2009) 10:348-55. doi:10.1038/ni.1714

19. Bette M, Kaut O, Schäfer MK, Weihe E. Constitutive expression of p55TNFR mRNA and mitogenspecific up-regulation of TNF alpha and p75TNFR mRNA in mouse brain. J Comp Neurol (2003) 465:417-30. doi:10.1002/cne.10877

20. Cheema ZF, Wade SB, Sata M, Walsh K, Sohrabji F, Miranda RC. Fas/Apo [apoptosis]-1 and associated proteins in the differentiating cerebral cortex: induction of caspase-dependent cell death and activation of NF-kappaB. J Neurosci (1999) 1999(19):1754-70.

21. Zuliani C, Kleber S, Klussmann S, Wenger T, Kenzelmann $\mathrm{M}$, Schreglmann $\mathrm{N}$, et al. Control of neuronal branching by the death receptor CD95 (Fas/Apo-1). Cell Death Differ (2006) 13:31-40. doi:10.1038/sj.cdd.4401720

22. Peter ME, Krammer PH. The CD95(APO-1/Fas) DISC and beyond. Cell Death Differ (2003) 10:26-35. doi:10.1038/sj.cdd.4401186

23. Gerhardt E, Kügler S, Leist M, Beier C, Berliocchi L, Volbracht C, et al. Cascade of caspase activation in potassium-deprived cerebellar granule neurons: targets for treatment with peptide and protein inhibitors of apoptosis. Mol Cell Neurosci (2001) 17:717-31. doi:10.1006/mcne.2001.0962

24. Putcha GV, Harris CA, Moulder KL, Easton RM, Thompson CB, Johnson EM Jr. Intrinsic and extrinsic pathway signaling during neuronal apoptosis: lessons from the analysis of mutant mice. J Cell Biol (2002) 157:441-53. doi:10.1083/jcb. 200110108

25. Jimenez S, Baglietto-Vargas D, Caballero C, Moreno-Gonzalez I, Torres M, Sanchez-Varo R, et al. Inflammatory response in the hippocampus of PS1M146L/APP751SL mouse model of Alzheimer's disease: age-dependent switch in the microglial phenotype from alternative to classic. J Neurosci (2008) 28:11650-61. doi:10.1523/ JNEUROSCI.3024-08.2008

26. Boissonneault V, Filali M, Lessard M, Relton J, Wong G, Rivest S. Powerful beneficial effects of macrophage colony-stimulating factor on beta-amyloid deposition and cognitive impairment in Alzheimer's disease. Brain (2009) 132:1078-92. doi:10.1093/brain/awn331

27. Beattie EC, Stellwagen D, Morishita W, Bresnahan JC, Ha BK, Von Zastrow M, et al. Control of synaptic strength by glial TNFalpha. Science (2002) 295:2282-5. doi:10.1126/science.1067859 
28. Stellwagen D, Malenka RC. Synaptic scaling mediated by glial TNF-alpha. Nature (2006) 440:1054-9. doi:10.1038/nature04671

29. Bertram L, McQueen MB, Mullin K, Blacker D, Tanzi RE. Systematic meta-analyses of Alzheimer disease genetic association studies: the AlzGene database. Nat Genet (2007) 39:17-23. doi:10.1038/ ng1934

30. Fillit H, Ding WH, Buee L, Kalman J, Altstiel L, Lawlor B, et al. Elevated circulating tumor necrosis factor levels in Alzheimer's disease. Neurosci Lett (1991) 129:318-20. doi:10.1016/03043940(91)90490-K

31. Tarkowski E, Blennow K, Wallin A, Tarkowski A. Intracerebral production of tumor necrosis factoralpha, a local neuroprotective agent, in Alzheimer disease and vascular dementia. J Clin Immunol (1999) 19:223-30. doi:10.1023/A:1020568013953

32. Chadwick W, Magnus T, Martin B, Keselman A, Mattson MP, Maudsley S. Targeting TNF-a receptors for neurotherapeutics. Trends Neurosci (2008) 10:504-11. doi:10.1016/j.tins.2008.07.005

33. He P, Zhong Z, Lindholm K, Berning L, Lee W, Lemere $C$, et al. Deletion of tumor necrosis factor death receptor inhibits amyloid beta generation and prevents learning and memory deficits in Alzheimer's mice. J Cell Biol (2007) 178:829-41. doi:10.1083/jcb.200705042

34. McAlpine FE, Lee J-K, Harms AS, Ruhn KA, Blurton-Jones $\mathrm{M}$, Hong J, et al. Inhibition of soluble TNF signaling in a mouse model of Alzheimer's disease prevents pre-plaque amyloid-associated neuropathology. Neurobiol Dis (2009) 1:163-77. doi:10.1016/j.nbd.2009.01.006

35. Tweedie D, Ferguson RA, Fishman K, Frankola KA, Van Praag H, Holloway HW, et al. Tumor necrosis factor-a synthesis inhibitor 3,6'-dithiothalidomide attenuates markers of inflammation, Alzheimer pathology and behavioral deficits in animal models of neuroinflammation and Alzheimer's disease. J Neuroinflammation (2012) 9:106-22. doi:10. 1186/1742-2094-9-106

36. McGeer PL, McGeer EG. Local neuroinflammation and the progression of Alzheimer's disease. J Neurovirol (2002) 8:529-38. doi:10.1080/ 13550280290100969

37. Li R, Yang L, Lindholm K, Konishi Y, Yue $\mathrm{X}$, Hampel $\mathrm{H}$, et al. Tumor necrosis factor death receptor signaling cascade is required for amyloid-beta protein-induced neuron death. J Neurosci (2004) 24:1760-71. doi:10.1523/ JNEUROSCI.4580-03.2004

38. Barger SW, Hörster D, Furukawa K, Goodman Y, Krieglstein J, Mattson MP. Tumor necrosis factors alpha and beta protect neurons against amyloid beta-peptide toxicity: evidence for involvement of a kappa B-binding factor and attenuation of peroxide and $\mathrm{Ca} 2+$ accumulation. Proc Natl Acad Sci US A (1995) 92:9328-32. doi:10.1073/pnas.92.20. 9328

39. Saha RN, Ghosh A, Palencia CA, Fung YK, Dudek SM, Pahan K. TNF-alpha preconditioning protects neurons via neuron-specific up-regulation of CREB-binding protein. J Immunol (2009) 183:2068-78. doi:10.4049/jimmunol.0801892

40. Micheau O, Tschopp J. Induction of TNF receptor I-mediated apoptosis via two sequential signaling complexes. Cell (2003) 114:181-90. doi:10.1016/ S0092-8674(03)00521-X

41. Marques-Fernandez F, Planells-Ferrer L, Gozzelino $\mathrm{R}$, Galenkamp KM, Reix S, Llecha-Cano $\mathrm{N}$, et al. TNF $\alpha$ induces survival through the FLIP-Ldependent activation of the MAPK/ERK pathway. Cell Death Dis (2013) 4:e493. doi:10.1038/cddis. 2013.25

42. Benn SC, Woolf CJ. Adult neuron survival strategies - slamming on the brakes. Nat Rev Neurosci (2004) 5:686-700. doi:10.1038/nrn1477
43. Segura MF, Sole C, Pascual M, Moubarak RS, Perez-Garcia MJ, Gozzelino R, et al. The long form of Fas apoptotic inhibitory molecule is expressed specifically in neurons and protects them against death receptor-triggered apoptosis. J Neurosci (2007) 27:11228-41. doi:10.1523/ JNEUROSCI.3462-07.2007

44. Yu LY, Saarma M, Arumäe U. Death receptors and caspases but not mitochondria are activated in the GDNF- or BDNF-deprived dopaminergic neurons. J Neurosci (2008) 28:7467-75. doi:10.1523/ JNEUROSCI.1877-08.2008

Conflict of Interest Statement: The authors declare that the research was conducted in the absence of any commercial or financial relationships that could be construed as a potential conflict of interest.

Received: 19 September 2014; accepted: 04 December 2014; published online: 18 December 2014.

Citation: Carriba P and Comella JX (2014) Amy-

loid beta, TNF $\alpha$ and FAIM-L; approaching new therapeutic strategies for AD. Front. Neurol. 5:276. doi: 10.3389/fneur.2014.00276

This article was submitted to Neuropharmacology, a section of the journal Frontiers in Neurology.

Copyright (c) 2014 Carriba and Comella. This is an open-access article distributed under the terms of the Creative Commons Attribution License (CC BY). The use, distribution or reproduction in other forums is permitted, provided the original author(s) or licensor are credited and that the original publication in this journal is cited, in accordance with accepted academic practice. No use, distribution or reproduction is permitted which does not comply with these terms. 